\title{
Trypanosoma cruzi entrance through systemic or mucosal infection sites differentially modulates regional immune response following acute infection in mice
}

\author{
Juliana de Meis*, Juliana Barreto de Albuquerque, Danielle Silva dos Santos, \\ Désio Aurélio Farias-de-Oliveira, Luiz Ricardo Berbert, Vinícius Cotta-de-Almeida and Wilson Savino
}

Laboratory of Thymus Research, Oswaldo Cruz Institute, Oswaldo Cruz Foundation, Rio de Janeiro, Brazil

\section{Edited by:}

Susan Swain, University of

Massachusetts Medical School, USA

Reviewed by:

Linda Cauley, University of

Connecticut Health Center, USA

Craig Michael Walsh, University of

California Irvine, USA

*Correspondence:

Juliana de Meis, Laboratory on

Thymus Research, Oswaldo Cruz

Institute, Oswaldo Cruz Foundation,

Avenue Brasil 4365, Manguinhos,

21045-360 Rio de Janeiro, Brazil

e-mail: jdemeis@ioc.fiocruz.br
Acute Chagas disease is characterized by a systemic infection that leads to the strong activation of the adaptive immune response. Outbreaks of oral contamination by the infective protozoan Trypanosoma cruzi are frequent in Brazil and other Latin American countries, and an increased severity of clinical manifestations and mortality is observed in infected patients. These findings have elicited questions about the specific responses triggered after T. cruzi entry via mucosal sites, possibly modulating local immune mechanisms, and further impacting regional and systemic immunity. Here, we provide evidence for the existence of differential lymphoid organ responses in experimental models of acute T. cruzi infection.

Keywords: Trypanosoma cruzi, lymph nodes, spleen, cytokine, T cell activation
Chagas disease (American Trypanosomiasis) is a neglected tropical illness caused by the hemoflagellate protozoan Trypanosoma cruzi. This infection is considered a world-wide health problem with a lack of treatment options due to the absence of a vaccine and global spreading $(1,2)$. Trypanosoma cruzi infection was initially endemic in rural areas of Latin America and, transmitted by contaminated insect vectors of the Reduviidae family. Insects become vectors after biting T. cruzi-infected animals or humans. The parasite can also be directly transmitted by blood transfusion and organ transplantation as well as orally and congenitally (3, 4). The incubation period (the time between T. cruzi exposure and development of symptoms) varies according to the infection route; for example, transmission by vector has an incubation time of 4-15 days. In cases of transfusion the incubation time ranges from 8 to 120 days, whereas in congenital transmission it varies from 3 to 22 days; roughly the same for oral transmission $(5,6)$. Today, the oral infection is the most common transmission route in the Brazilian Amazon region after the pan-American Health Organization declared the abrogation of vectorial transmission in the area (5). Interestingly, oral transmission has been associated with high mortality and morbidity due to an increased prevalence and severity of cardiac pathology (myocarditis) (7-10).

\section{TRYPANOSOMA CRUZI INFECTION TARGETS SEVERAL TISSUES IN THE HOST}

During the acute phase of the disease, the parasites highly replicate in tissues (under amastigote form), and infective trypomastigote forms are numerous in the blood. Throughout this phase, $T$. cruzi is able to infect many host tissues, including skeletal muscle, lymphoid and nervous tissues, endocrine glands, and mucose (Table 1).
In immunocompetent hosts, the high parasitemia observed in the acute phase is quickly controlled through immune effector mechanisms. As a result, T. cruzi numbers in the blood and tissues drop drastically to almost undetectable levels as the infected individual enters the chronic phase. Nevertheless, in situ PCR (Polymerase Chain Reaction) and confocal analyses have shown that even in the chronic phase, tissues are not parasite-free (1118). Several tissues, including the heart and the nervous system, as well as adipocytes, retain amastigote forms that perpetuate the chronic infection (19-21). Additionally, Chagas disease may be reactivated during periods of immunosuppression, such as in patients with HIV/AIDS or undergoing immunosuppressive drug therapy $(22,23)$.

Although controlled, T. cruzi persistence in tissues appears to be associated with inflammatory lesions and disease severity in the chronic phase $(12,13,18,24-28)$. Using two models of chronic infection, Zhang and Tarleton (18) demonstrated that parasite clearance from tissues resulted in the disappearance of associated inflammatory lesions and resolution of disease. Taken together, these studies clearly demonstrate that Chagas disease is a systemic infection and that the immune response is important in containing T. cruzi replication in the acute phase which impacts disease severity during the chronic phase of the infection.

\section{SYSTEMIC OR MUCOSAL ROUTES OF T. CRUZI INFECTION DIFFERENTIALLY AFFECT PARASITE LOAD AND MORTALITY IN MICE}

Experimental models of T. cruzi infection have been widely used to study various aspects of the pathogenesis and pathophysiology of Chagas disease. In fact, the vast majority of our knowledge on the biology of T. cruzi infection was initially obtained 
Table 1 | Tissue infectivity of Trypanosoma cruzi in mammals.

\begin{tabular}{|c|c|c|c|c|}
\hline Target tissue & \multicolumn{2}{|c|}{ Human } & \multicolumn{2}{|l|}{ Animals } \\
\hline Adrenal gland & ND & ND & $\begin{array}{l}\text { Buckner et al. (77), Correa-de-Santana et al. } \\
\text { (79) }\end{array}$ & ND \\
\hline Blood & $\begin{array}{l}\text { Qvarnstrom et al. } \\
\text { (80) }\end{array}$ & $\begin{array}{l}\text { Moreira et al. (11), } \\
\text { Qvarnstrom et al. } \\
\text { (80) }\end{array}$ & $\begin{array}{l}\text { Hoft et al. (69), Buckner et al. (77), Cortez et } \\
\text { al. (81), Guillermo et al. (55), Silva et al. (57), } \\
\text { Veloso et al. (82), Castro-Sesquen et al. (83) }\end{array}$ & $\begin{array}{l}\text { Veloso et al. (82), } \\
\text { Castro-Sesquen et al. (83) }\end{array}$ \\
\hline Bone & ND & ND & Morocoima et al. (84) & ND \\
\hline Bone marrow & $\begin{array}{l}\text { Baena Teran et al. } \\
\text { (85) }\end{array}$ & ND & Morocoima et al. (84) & ND \\
\hline $\begin{array}{l}\text { Central Nervous } \\
\text { System }\end{array}$ & Mortara et al. (19) & Mortara et al. (19) & $\begin{array}{l}\text { Andrade et al. (87), Buckner et al. (77), } \\
\text { Guarner et al. (78), Rachid et al. (88) }\end{array}$ & $\begin{array}{l}\text { Andrade et al. (87), } \\
\text { Guarner et al. (78) }\end{array}$ \\
\hline $\begin{array}{l}\text { Gastro Intestinal } \\
\text { Tract }\end{array}$ & Mortara et al. (19) & ND & $\begin{array}{l}\text { Andrade et al. (87), Buckner et al. (77), } \\
\text { Guarner et al. (78) }\end{array}$ & $\begin{array}{l}\text { Andrade et al. (87), } \\
\text { Guarner et al. (78) }\end{array}$ \\
\hline Heart & Mortara et al. (19) & $\begin{array}{l}\text { Mortara et al. (19), } \\
\text { Vago et al. (89), } \\
\text { Schijman et al. (90) }\end{array}$ & $\begin{array}{l}\text { Andrade et al. (87), Buckner et al. (77), } \\
\text { Guarner et al. (78), Combs et al. (20), } \\
\text { Castro-Sesquen et al. (83) }\end{array}$ & $\begin{array}{l}\text { Guarner et al. (78), Combs } \\
\text { et al. (20), Castro-Sesquen } \\
\text { et al. (83) }\end{array}$ \\
\hline Liver & ND & ND & $\begin{array}{l}\text { Hoft et al. (69), Buckner et al. (77), Guarner et } \\
\text { al. (78) }\end{array}$ & ND \\
\hline Peritoneal cells & ND & ND & Silva et al. (57) & ND \\
\hline Skin & (19) & Mortara et al. (19) & ND & ND \\
\hline Spleen & ND & ND & $\begin{array}{l}\text { Hoft et al. (69), Buckner et al. (77), Guarner et } \\
\text { al. (78), Combs et al. (20), Giddings et al. (74) }\end{array}$ & $\begin{array}{l}\text { Guarner et al. (78), Combs } \\
\text { et al. (20) }\end{array}$ \\
\hline Stomach/esophagus & ND & Vago et al. (91) & $\begin{array}{l}\text { Hoft et al. (69), Guarner et al. (78), Cortez et } \\
\text { al. (81), Staquicini et al. (92) }\end{array}$ & Guarner et al. (78) \\
\hline Thymus & ND & ND & Da Costa et al. (86) & ND \\
\hline kidney & (19) & ND & $\begin{array}{l}\text { Buckner et al. (77), Guarner et al. (78), } \\
\text { Castro-Sesquen et al. (83) }\end{array}$ & $\begin{array}{l}\text { Guarner et al. (78), } \\
\text { Castro-Sesquen et al. (83) }\end{array}$ \\
\hline nasal cavity & ND & ND & Giddings et al. (74) & ND \\
\hline Bladder & ND & ND & Buckner et al. (77) & Buckner et al. (77) \\
\hline
\end{tabular}

$N D$ - not detected. 
using experimental mouse models. It is well established that the immune response and immunopathologic manifestations following T. cruzi infection are dependent on genetically heterogeneous host populations, parasite strain, inoculum size, and route of infection. Moreover, the anatomical route of pathogen invasion may directly impact upon the host immune response and host resistance (Box 1). In this way, several studies compared mucosal and systemic T. cruzi infection and mortality in mice.

In 1967, Marsden showed that CFI mice infected with the Peruvian strain of T. cruzi by systemic routes [intraperitoneal (i.p.), intravenous (i.v.), or subcutaneous (s.c.)] showed higher infection rates $(67-100 \%)$ and mortality than mucosal routes [oral (o.i.), intragastric (i.g.), intrarectal (i.r.), genitalia (gen.), or conjunctival (cnj.)] (17-67\%) (29). Similar results were observed in a study by Camandaroba et al. (30) in which i.p. and i.g. inoculation with the Peruvian and Colombian strains of T. cruzi were compared in Swiss mice. Caradonna and Pereiraperrin (31) infected BALB/c and C57BL/6 mice with the Tulahuén strain of T. cruzi via s.c. and intranasal (i.n.) routes and observed higher mortality in the s.c. group. Interestingly, mice infected via the i.n. route developed higher brain parasitism and lower blood parasitemia than animals infected via the s.c. route, suggesting a preferential homing of the parasite to the brain after i.n. administration (31).

Taken together, these observations suggest that the route of parasite entry into the host is a key factor in Chagas pathogenesis. It is logical to think that following parasite entry, the initial target tissues/cells in the circulation (Table 2) may contribute to the development of an immune response able to control infection.

\section{SYSTEMIC TRYPANOSOMA CRUZI ENTRY INDUCES A DIFFERENTIAL RESPONSE IN SECONDARY LYMPHOID ORGANS OF INFECTED MICE}

Acute and chronic T. cruzi infections promote significant increases in the size and numbers of cells in the subcutaneous lymph nodes (SCLN) and spleen (SP), likely due to persistent T and B cell polyclonal activation in these tissues $(32,33)$. Parasite-derived proteins, such as trans-sialidase and racemase, as well as $T$. cruzi-derived DNA have been shown to contribute to lymphocyte proliferation in Chagas disease (34-36). Interestingly, the majority of polyclonal lymphocytes activated during early T. cruzi infection do not appear to be parasite-specific (37-45). However, the relative role of $\mathrm{T}$ and $\mathrm{B}$ cells in controlling $T$. cruzi infection remains controversial. Although there are data showing that $\mathrm{T}$ and $\mathrm{B}$ cell activation is necessary for limiting T. cruzi expansion, the polyclonal activation also appears to contribute to the pathological alterations observed in Chagas disease $(44,46,47)$. Similarly to splenocytes, SCLN-derived effector $\mathrm{T}$ cells from infected mice secrete high amounts of IL-2, IL-4, IL-10, and IFN- $\gamma$, suggesting the existence of a mixed type- 1 and type- 2 profiles of cytokine secretion $(48,49)$.

The process of expansion and contraction by the lymphocyte population in the secondary lymphoid organs can be regarded as a regional response to systemic T. cruzi infection. Gut-associated lymphoid tissues are specialized for draining antigens present in the gastrointestinal tract and are also involved in the tolerogenic immune response. In this respect, gut-associated lymphoid tissues may be involved in the progressive damage of the digestive
Box 1 | T cell differentiation into effector cells following bacterial infections may be differentially programed depending on the route of pathogen presentation $(96,97)$.

Accordingly, intravenous infection generates IFN- $\gamma$-producing $\mathrm{T}$ cells, whereas the mucosal routes of infection (e.g., intranasal or intragastric) generate IL-17-producing $T$ cells. These results are in keeping with the observation that spleen-derived antigenpresenting (APC) cells are prone to producing IL-12, a cytokine involved in Th1 differentiation, whereas mucosal APC rather produce IL-6 and TGF- $\beta$, cytokines that selectively drive the Th17 differentiation program (98). In addition, it is interesting to note that these route-driven programs of $T$ cell differentiation may be involved in the fine tuning of innate receptors for bacterial molecules (96) and influence the ability to generate an efficient memory pool of effector cells (97).

Table 2 | Primary distribution of $T$. cruzi in infected mice.

\begin{tabular}{|c|c|c|}
\hline Route of infection & First target tissues/cells & Reference \\
\hline Intravenous & $\begin{array}{l}\text { Blood, liver, spleen, lungs, and } \\
\text { kidneys/macrophages }\end{array}$ & Kuhn et al. (93) \\
\hline Intraperitoneal & Peritoneal macrophages & Nogueira et al. (94 \\
\hline Oral & $\begin{array}{l}\text { Stomach (epithelial cells), } \\
\text { drainage lymph node }\end{array}$ & $\begin{array}{l}\text { Hoft et al. (69), } \\
\text { Yoshida (95) }\end{array}$ \\
\hline Conjunctival & $\begin{array}{l}\text { Nasolacrimal ducts and nasal } \\
\text { cavities (epithelial cells), parotid, } \\
\text { and submandibular lymph node }\end{array}$ & Giddings et al. (74) \\
\hline
\end{tabular}

system (megacolon and megaesophagus) that is a consequence of chronic T. cruzi infection (50-52). For these reasons, the mesenteric lymph nodes (MLN) and Peyer's Patches (PP) are also studied in systemic infections, since they may be involved in the gut pathological changes that are observed in infected patients. In contrast to the hyperplasia of the SP and SCLN observed in infected mice, there is a reduction in the size and cell number of the MLN and PP, possibly due to the increased depletion of $\mathrm{T}$ and $\mathrm{B}$ lymphocytes $(49,53,54)$.

As a consequence of cell activation, T lymphocyte apoptosis is also observed in lymphoid tissues (Box 2). In fact, the Fas molecule is one candidate to regulate $\mathrm{T}$ and $\mathrm{B}$ lymphocyte responses in both the SP and SCLN during the acute infection $(33,54,55)$. For example, it has been shown that Fas selectively kills activated $\mathrm{IgG}^{+}$ $B$ lymphocytes with specificities for parasite antigens (56). Moreover, SP-derived $\mathrm{CD}^{+}$and $\mathrm{CD}^{+}{ }^{+} \mathrm{T}$ cells respond to Fas-induced apoptosis, as they demonstrate increased Fas/FasL expression and caspase- 8 activation during acute infection $(48,55)$. In agreement with these data, it has been shown that the in vivo injection of anti-FasL and a general caspase inhibitor (zVAD-fmk) into acutely infected mice impairs $\mathrm{T}$ and $\mathrm{B}$ lymphocyte death and improves the host immune response to infection in both SCLN and SP $(55,57)$. Blockade of activated $\mathrm{CD}^{+}{ }^{+} \mathrm{T}$ cell death increases IFN- $\gamma$ secretion by splenocytes in the initial stages of infection, and IL- 4 and IL-10 are induced at later stages $(55,58)$. 


\section{Box 2 |T cell apoptosis can be stimulated in secondary lymphoid organs by features such as activation-induced cell death (AICD), granzymes, or growth factor withdrawal $(59,60)$.}

The abundance of antigens and cytokine production (IL-2) in the microenvironment is essential to trigger the cell death pathway (60). In the presence of a given antigen, IL-2 prompt T cells to die by AICD, through activation of death receptor molecules (Fas or TNF-R and caspase-8 activation) (61-63). The absence of antigen, deprivation of cytokines or cytotoxic factors (such as oxidative stress and glucocorticoids) initiates the intrinsic apoptotic pathway, regulated by anti-apoptotic BCL-2 family members that can be divided into three subgroups of proteins: (1) the pro-survival members (Bcl-2, Bcl-xL, Mcl-1, A1/Bfl-1, and Bcl-w); (2) the proapoptotic BH3-only proteins (Bim, Bid, Puma, Bad, Bmf, Hrk, Bik, and Noxa) activated transcriptionally, post-transcriptionally, or post-translationally by cytotoxic factors; and (3) multi-BH domain pro-apoptotic protein (Bak and Bax) (64-67). The intrinsic pathway of death involves mitochondrial membrane permeabilization, cytochrome c release into the cytoplasm, activation of caspase-9, and downstream effector caspases (61). Interestingly, regulatory $T$ cells deprives the effector T cells of growth factors (such as IL-2), which causes either proliferation arrest and apoptosis mediated by growth factor withdrawal $(59,68)$.

Diminished numbers of MLN and PP lymphocytes from $T$. cruzi-infected mice appear to be associated with differences in lymphocyte activation, proliferation, and apoptosis. MLN-derived cells from infected mice show reduced numbers of proliferating lymphocytes in vivo and decreased cytokine production (IL-2, IL-4, IL-10) in vitro by activated T cells, which have been demonstrated to produce mainly type- 1 cytokines $(33,49)$. In addition to Fas, TNFR1/p55-mediated signaling and IL-4 deprivation through caspase- 9 activation are involved in T cell death and consequent MLN atrophy seen in the course of acute infection $(33,49)$. These data suggest that distinct mechanisms are involved in lymphocyte contraction events.

These studies demonstrated that lymphocyte apoptosis in secondary lymphoid organs represents an important feature of the immune response to a given pathogen. In agreement, the in vivo administration of zVAD-fmk reduces lymphocyte apoptosis in secondary lymphoid tissues and increases host resistance to T. cruzi infection (49). Moreover, SP or MLN cells are involved in the host immune response, as splenectomy or MLN excision prior to $T$. cruzi infection in mice increases susceptibility to infection with elevated blood parasitemia $(49,54)$. In this context, further studies are necessary to approach apoptosis-associated molecules that might be operating as a consequence of regional response following $\mathrm{T}$ cell activation and regulation in the course of T. cruzi infection (Box 2).

\section{DOES A DISTINCT ROUTE OF INFECTION INTERFERE WITH SECONDARY LYMPHOID ORGAN DYNAMICS?}

Previous data have revealed that oral T. cruzi inoculation results in blood parasitemia and heart tissue parasitism, thereby clearly indicating a systemic infection $(30,69,70)$. A primary infection with insect-derived infective forms delivered orally resulted in parasite replication within epithelial cells of the gastric mucosa (69).
This initial invasion is related to establishment of a progressive gastritis and allows further systemic dissemination of the parasite. Nonetheless, the short replication period at this mucosal site induces specific immunity, as protection was observed after a secondary mucosal challenge. Such protection apparently involves the specific production of IgA and IgG (69) and possibly employs CCR5-CCL5 signaling (71).

Protection may also be due to IFN- $\gamma$-producing lymphocytes as indicated by their increased frequency in the gastric mucosa and draining lymph nodes of orally infected mice (69). Moreover, a mucosal vaccination approach leading to polarized type-1 or type2 responses (72) as well as the mucosal challenge of genetically deficient mice (73) reinforced the central role for a type-1 response in providing protection following mucosal infection. Interestingly, these humoral and cellular responses are also protective after parasite inoculation in the conjunctival mucosa, a natural portal of entry for $T$. cruzi that leads to nasal infection with subsequent systemic spreading (74).

Following outbreaks of oral contamination by T. cruzi, a clear increase in the severity of clinical manifestations was observed in infected patients compared with other types of transmission routes $(7,75)$. These observations raise important questions concerning the particular features of T. cruzi entry via the mucosa, including the possible modulation of local immune mechanisms and the impact on regional and systemic immunity. In fact, we have previously shown that mice infected via both the i.p. and s.c. routes show similar parasitemia and induce SCLN expansion as well as MLN atrophy (33). Interestingly, the s.c. route induced higher SCLN cell expansion and similar MLN atrophy at the peak of parasitemia when compared with the i.p. route. These data suggest that unlike SCLN cells, MLN lymphocytes are similarly affected upon infection using both inoculation routes (33).

One can argue that an oral or intragastric infection might impact more severely on the mucosal associated lymphoid organs than the SCLN and SP. We still lack information regarding SCLN behavior in oral infection, but hyperplasia of the lymphoid follicles in the SP has been reported (30). Additionally, Hoft et al. (69) showed that after oral T. cruzi infection, BALB/c mice had an increase in gastric lymph node size. In this study, the analysis of cytokine production by gastric lymph node cells and splenocytes showed that IFN- $\gamma$ and IL-4 were produced in these tissues. These data indicate that in both systemic and mucosal infections splenocytes exhibit a mixed type- 1 and type- 2 profile of cytokine secretion (48, 49, 69). Regarding the MLN response upon oral infection, no data have been reported in the literature. Therefore, a comparative analysis of oral infections versus other infection routes should be critically performed to better understand the immune mechanisms that are involved in the response to mucosal T. cruzi infection.

\section{CONCLUSION AND PERSPECTIVES}

Chagas disease is characterized by both protective and immunopathogenic responses. An antigenic challenge in the host elicits a complex protective immune response that includes both inflammatory and regulatory networks. These networks are observed after T. cruzi infection and are induced due to 
systemic infection. However, different routes of parasite entry may impact these immune circuits, define particular regional immune responses, and perhaps change the existing view of how the host mounts a protective immune response. Thus, the current microepidemic of the oral transmission of Chagas disease prompts revisiting previous findings (99). More importantly, new studies

\section{REFERENCES}

1. Hotez PJ, Molyneux DH, Stillwaggon E, Bentwich Z, Kumaresan J. Neglected tropical diseases and HIV/AIDS. Lancet (2006) 368:1865-6. doi:10.1016/S01406736(06)69765-1

2. Savino W, Villa-Verde DM, Mendes-Da-Cruz DA, SilvaMonteiro E, Perez AR, Aoki Mdel P, et al. Cytokines and cell adhesion receptors in the regulation of immunity to Trypanosoma cruzi. Cytokine Growth Factor Rev (2007) 18:107-24. doi:10.1016/j.cytogfr.2007.01.010

3. Dorn P, Buekens P, Hanford E. Whac-a-mole: future trends in Chagas transmission and the importance of a global perspective on disease control. Future Microbiol (2007) 2:365-7. doi:10.2217/ 17460913.2.4.365

4. Tarleton RL, Reithinger R, Urbina JA, Kitron U, Gurtler RE. The challenges of Chagas disease - grim outlook or glimmer of hope. PLoS Med (2007) 4:e332. doi:10.1371/journal. pmed.0040332

5. Sanchez LV, Ramirez JD. Congenital and oral transmission of American trypanosomiasis: an overview of physiopathogenic aspects. Parasitology (2012) 140:147-59. doi:10. 1017/S0031182012001394

6. Bisio M, Seidenstein ME, Burgos JM, Ballering G, Risso M, Pontoriero $\mathrm{R}$, et al. Urbanization of congenital transmission of Trypanosoma cruzi: prospective polymerase chain reaction study in pregnancy. Trans $R$ Soc Trop Med Hyg (2011) 105:543-9. doi:10.1016/j.trstmh.2011.07.003

7. Barbosa-Ferreira JM, Guerra JA, Santana Filho FS, Magalhaes BM, Coelho LI, Barbosa MG. Cardiac involvement in Acute Chagas disease cases in the Amazon region. Arq Bras Cardiol (2010) 94:147-9. doi:10.1590/S0066782X2010000600023

8. Pinto AY, Harada GS, Valente V, Abud JE, Gomes F, Souza GC, et al. Cardiac attacks in patients with acute Chagas disease in a family micro-outbreak, in Abaetetuba, Brazilian Amazon. Rev Soc Bras Med Trop (2001) 34:413-9.
9. Vinas Albajar P, Laredo SV, Terrazas MB, Coura JR. Dilated cardiomyopathy in patients with chronic Chagasic infection: report of two fatal autochthonous cases from Rio Negro, State of Amazonas, Brazil. Rev Soc Bras Med Trop (2003) 36:401-7.

10. Ianni BM, Mady C. The sugarcane juice was delicious, but. Arq Bras Cardiol (2005) 85:379-81.

11. Moreira OC, Ramirez JD, Velazquez E, Melo MF, LimaFerreira C, Guhl F, et al. Towards the establishment of a consensus real-time $\mathrm{qPCR}$ to monitor Trypanosoma cruzi parasitemia in patients with chronic Chagas disease cardiomyopathy: a substudy from the BENEFIT trial. Acta Trop (2013) 125:23-31. doi:10.1016/j. actatropica.2012.08.020

12. Jones EM, Colley DG, Tostes S, Lopes ER, Vnencak-Jones CL, McCurley TL. Amplification of a Trypanosoma cruzi DNA sequence from inflammatory lesions in human Chagasic cardiomyopathy. Am J Trop Med Hyg (1993) 48:348-57.

13. Brandariz S, Schijman A, Vigliano C, Arteman P, Viotti R, Beldjord C, et al. Detection of parasite DNA in Chagas' heart disease. Lancet (1995) 346:1370-1. doi:10. 1016/S0140-6736(95)92388-8

14. Vago AR, Macedo AM, Adad SJ, Reis DD, Correa-Oliveira R. PCR detection of Trypanosoma cruzi DNA in oesophageal tissues of patients with chronic digestive Chagas' disease. Lancet (1996) 348:891-2. doi:10.1016/S01406736(05)64761-7

15. Vago AR, Macedo AM, Oliveira RP, Andrade LO, Chiari E, Galvao LM, et al. Kinetoplast DNA signatures of Trypanosoma cruzi strains obtained directly from infected tissues. Am J Pathol (1996) 149:2153-9.

16. Lane JE, Olivares-Villagomez D, Vnencak-Jones CL, McCurley TL, Carter CE. Detection of Trypanosoma cruzi with the polymerase chain reaction and in situ hybridization in infected murine cardiac tissue. Am J Trop Med Hyg (1997) 56:588-95.

investigating the influence of a primary infection with the parasite through mucose should be performed.

\section{ACKNOWLEDGMENTS}

This work was funded with grants from Fiocruz, CNPq, and Faperj (Brazil).

17. Olivares-Villagomez D, McCurley TL, Vnencak-Jones CL, CorreaOliveira R, Colley DG, Carter CE. Polymerase chain reaction amplification of three different Try panosoma cruzi DNA sequences from human Chagasic cardiac tissue. Am J Trop Med Hyg (1998) 59:563-70.

18. Zhang L, Tarleton RL. Parasite persistence correlates with disease severity and localization in chronic Chagas' disease. J Infect Dis (1999) 180:480-6. doi:10.1086/314889

19. Mortara RA, Da Silva S, Patricio FR, Higuchi ML, Lopes ER, Gabbai AA, et al. Imaging Trypanosoma cruzi within tissues from Chagasic patients using confocal microscopy with monoclonal antibodies. Parasitol Res (1999) 85:800-8. doi:10. 1007/s004360050636

20. Combs TP, Nagajyothi F, Mukherjee S, De Almeida CJ, Jelicks LA, Schubert W, et al. The adipocyte as an important target cell for Trypanosoma cruzi infection. J Biol Chem (2005) 280:24085-94. doi:10. 1074/jbc.M412802200

21. Ferreira AV, Segatto M, Menezes $Z$, Macedo AM, Gelape C, De Oliveira Andrade L, et al. Evidence for Trypanosoma cruzi in adipose tissue in human chronic Chagas disease. Microbes Infect (2011) 13:1002-5 doi:10.1016/j.micinf.2011.06.002

22. Sartori AM, Ibrahim KY, Nunes Westphalen EV, Braz LM, Oliveira OC Jr, Gakiya E, et al. Manifestations of Chagas disease (American trypanosomiasis) in patients with HIV/AIDS. Ann Trop Med Parasitol (2007) 101:31-50. doi:10.1179/ 136485907X154629

23. Fiorelli AI, Santos RH, Oliveira JL Jr, Lourenco-Filho DD, Dias RR, Oliveira AS, et al. Heart transplantation in 107 cases of Chagas' disease. Transplant Proc (2011) 43:2204. doi:10.1016/j.transproceed.2010. 12.046

24. Ben Younes-Chennoufi A Hontebeyrie-Joskowicz M, Tricottet V, Eisen H, Reynes M, Said G. Persistence of Trypanosoma cruzi antigens in the inflammatory lesions of chronically infected mice. Trans $\mathrm{R}$ Soc Trop Med Hyg
(1988) 82:77-83. doi:10.1016/ 0035-9203(88)90269-6

25. Higuchi M, Brito T, Reis M, Barbosa A, Bellotti G, Pereira-Barreto A, et al. Correlation between Trypanosoma cruzi parasitism and myocardial inflammatory infiltrate in human chronic Chagasic myocarditis: light microscopy and immunohistochemical findings. Cardiovasc Pathol (1993) 2:101-6. doi:10.1016/1054-8807(93)90021$\mathrm{S}$

26. Bellotti G, Bocchi EA, De Moraes AV, Higuchi ML, Barbero-Marcial $\mathrm{M}$, Sosa $\mathrm{E}$, et al. In vivo detection of Trypanosoma cruzi antigens in hearts of patients with chronic Chagas' heart disease. Am Heart J (1996) 131:301-7. doi:10.1016/ S0002-8703(96)90358-0

27. Reis MM, Higuchi Mde L, Benvenuti LA, Aiello VD, Gutierrez PS, Bellotti G, et al. An in situ quantitative immunohistochemical study of cytokines and IL-2R+ in chronic human Chagasic myocarditis: correlation with the presence of myocardial Trypanosoma cruzi antigens. Clin Immunol Immunopathol (1997) 83:165-72. doi:10.1006/clin. 1997.4335

28. Tarleton RL, Zhang L, Downs MO. "Autoimmune rejection" of neonatal heart transplants in experimental Chagas disease is a parasitespecific response to infected host tissue. Proc Natl Acad Sci U S A (1997) 94:3932-7. doi:10.1073/ pnas.94.8.3932

29. Marsden PD. Trypanosoma cruzi infections in CFI mice. II. Infections induced by different routes. Ann Trop Med Parasitol (1967) 61:62-7.

30. Camandaroba EL, Pinheiro Lima CM, Andrade SG. Oral transmission of Chagas disease: importance of Trypanosoma cruzi biodeme in the intragastric experimental infection. Rev Inst Med Trop Sao Paulo (2002) 44:97-103. doi:10. 1590/S0036-46652002000200008

31. Caradonna K, Pereiraperrin M. Preferential brain homing following intranasal administration of Trypanosoma cruzi. Infect Immun (2009) 77:1349-56. doi:10.1128/ IAI.01434-08 
32. Minoprio PM, Coutinho A, Joskowicz M, D'Imperio Lima MR, Eisen $\mathrm{H}$. Polyclonal lymphocyte responses to murine Trypanosoma cruzi infection. II. Cytotoxic T lymphocytes. Scand J Immunol (1986) 24:66979. doi:10.1111/j.1365-3083.1986. tb02186.x

33. de Meis J, Mendes-Da-Cruz DA, Farias-De-Oliveira DA, Correa-DeSantana E, Pinto-Mariz F, CottaDe-Almeida V, et al. Atrophy of mesenteric lymph nodes in experimental Chagas' disease: differential role of Fas/Fas-L and TNFRI/TNF pathways. Microbes Infect (2006) 8:221-31. doi:10. 1016/j.micinf.2005.06.027

34. Bryan MA, Norris KA. Genetic immunization converts the Trypanosoma cruzi B-Cell mitogen proline racemase to an effective immunogen. Infect Immun (2010) 78:810-22. doi:10.1128/IAI.0092609

35. Reina-San-Martin B, Degrave W, Rougeot C, Cosson A, Chamond $\mathrm{N}$, Cordeiro-Da-Silva A, et al. A Bcell mitogen from a pathogenic trypanosome is a eukaryotic proline racemase. Nat Med (2000) 6:890-7. doi:10.1038/78651

36. Buschiazzo A, Goytia M, Schaeffer F, Degrave W, Shepard W, Gregoire C, et al. Crystal structure, catalytic mechanism, and mitogenic properties of Trypanosoma cruzi proline racemase. Proc Natl Acad Sci U S A (2006) 103:1705-10. doi:10.1073/ pnas.0509010103

37. Rodriguez AM, Santoro F, Afchain D, Bazin H, Capron A. Trypanosoma cruzi infection in B-cell-deficient rats. Infect Immun (1981) 31:524-9.

38. Minoprio P, Burlen O, Pereira P, Guilbert B, Andrade L, Hontebeyrie-Joskowicz $\mathrm{M}$, et al. Most B cells in acute Trypanosoma cruzi infection lack parasite specificity. Scand J Immunol (1988) 28:553-61. doi:10.1111/j.13653083.1988.tb01487.x

39. Minoprio P, Coutinho A, Spinella S, Hontebeyrie-Joskowicz M. Xid immunodeficiency imparts increased parasite clearance and resistance to pathology in experimental Chagas' disease. Int Immunol (1991) 3:427-33. doi:10.1093/intimm/3.5.427

40. Yoshida N, Araya JE, Da Silveira JF, Giorgio S. Trypanosoma cruzi: antibody production and $\mathrm{T}$ cell response induced by stage-specific surface glycoproteins purified from metacyclic trypomastigotes. Exp Parasitol (1993) 77:405-13. doi:10.1006/ expr. 1993.1100
41. Freire-de-Lima C, Pecanha LM, Dos Reis GA. Chronic experimental Chagas' disease: functional syngeneic T-B-cell cooperation in vitro in the absence of an exogenous stimulus. Infect Immun (1996) 64: 2861-6.

42. De Arruda Hinds LB, AlexandreMoreira MS, Decote-Ricardo D, Nunes MP, Pecanha LM. Increased immunoglobulin secretion by B lymphocytes from Trypanosoma cruzi infected mice after B lymphocytes-natural killer cell interaction. Parasite Immunol (2001) 23:581-6. doi:10.1046/j. 1365-3024.2001.00418.x

43. Girones N, Rodriguez CI, CarrascoMarin E, Hernaez RF, De Rego JL, Fresno M. Dominant T- and B-cell epitopes in an autoantigen linked to Chagas' disease. J Clin Invest (2001) 107:985-93. doi:10.1172/JCI10734

44. Gao W, Wortis HH, Pereira MA. The Trypanosoma cruzi trans-sialidase is a $\mathrm{T}$ cell-independent $\mathrm{B}$ cell mitogen and an inducer of nonspecific Ig secretion. Int Immunol (2002) 14:299-308. doi:10.1093/ intimm/14.3.299

45. Acosta Rodriguez EV, Zuniga EI, Montes CL, Merino MC, Bermejo DA, Amezcua Vesely MC, et al. Trypanosoma cruzi infection beats the B-cell compartment favouring parasite establishment: can we strike first? Scand J Immunol (2007) 66:137-42. doi:10.1111/j. 1365-3083.2007.01968.x

46. Tarleton RL, Grusby MJ, Postan M, Glimcher LH. Trypanosoma cruzi infection in MHC-deficient mice: further evidence for the role of both class I- and class II-restricted T cells in immune resistance and disease. Int Immunol (1996) 8:13-22. doi:10. 1093/intimm/8.1.13

47. Millar AE, Kahn SJ. The SA851.1 protein of the Trypanosoma cruzi trans-sialidase superfamily is a dominant T-cell antigen. Infect Immun (2000) 68:3574-80. doi:10. 1128/IAI.68.6.3574-3580.2000

48. Silva EM, Guillermo LV, RibeiroGomes FL, De Meis J, Pereira $\mathrm{RM}, \mathrm{Wu} \mathrm{Z}$, et al. Caspase-8 activity prevents type 2 cytokine responses and is required for protective $\mathrm{T}$ cell-mediated immunity against Trypanosoma cruzi infection. J Immunol (2005) 174: 6314-21.

49. de Meis J, Ferreira LM, Guillermo LV, Silva EM, Dosreis GA, Lopes MF. Apoptosis differentially regulates mesenteric and subcutaneous lymph node immune responses to Trypanosoma cruzi. Eur J Immunol
(2008) 38:139-46. doi:10.1002/eji. 200737582

50. Florez O, Esper J, Higuera S, Barraza MF, Cabrera $\mathrm{HB}$, Mantilla JC et al. Chagasic megacolon associated with Trypanosoma cruzi I in a Colombian patient. Parasitol Res (2010) 107:439-42. doi:10. 1007/s00436-010-1874-2

51. Teixeira AR, Nitz N, Guimaro MC, Gomes C, Santos-Buch CA. Chagas disease. Postgrad Med J (2006) 82:788-98. doi:10.1136/pgmj.2006. 047357

52. da Silveira AB, Lemos EM, Adad SJ, Correa-Oliveira R, Furness JB, D'Avila Reis D. Megacolon in Chagas disease: a study of inflammatory cells, enteric nerves, and glial cells. Hum Pathol (2007) 38:1256-64. doi: 10.1016/j.humpath.2007.01.020

53. Antunez MI, Feinstein RE, Cardoni RL, Gronvik KO. Trypanosoma cruzi: $\mathrm{T}$ cell subpopulations in the Peyer's patches of $\mathrm{BALB} / \mathrm{c}$ infected mice. Exp Parasitol (1997) 87:58-64. doi:10.1006/expr.1997.4171

54. de Meis J, Morrot A, FariasDe-Oliveira DA, Villa-Verde DM, Savino W. Differential regional immune response in Chagas disease. PLoS Negl Trop Dis (2009) 3:e417. doi:10.1371/journal.pntd.0000417

55. Guillermo LV, Silva EM, RibeiroGomes FL, De Meis J, Pereira WF, Yagita $\mathrm{H}$, et al. The Fas death pathway controls coordinated expansions of type 1 CD8 and type 2 CD4 $\mathrm{T}$ cells in Trypanosoma cruzi infection. J Leukoc Biol (2007) 81:94251. doi:10.1189/jlb.1006643

56. Zuniga E, Motran CC, Montes CL, Yagita H, Gruppi A. Trypanosoma cruzi infection selectively renders parasite-specific IgG+ B lymphocytes susceptible to Fas/Fas ligandmediated fratricide. I Immunol (2002) 168:3965-73.

57. Silva EM, Guillermo LV, RibeiroGomes FL, De Meis J, Nunes MP, Senra JF, et al. Caspase inhibition reduces lymphocyte apoptosis and improves host immune responses to Trypanosoma cruzi infection. Eur J Immunol (2007) 37:738-46. doi:10. 1002/eji.200636790

58. Lopes MF, Guillermo LV, Silva EM. Decoding caspase signaling in host immunity to the protozoan Try panosoma cruzi. Trends Immunol (2007) 28:366-72. doi:10.1016/j.it. 2007.06.004

59. Pandiyan P, Zheng L, Lenardo MJ. The molecular mechanisms of regulatory T cell immunosuppression. Front Immunol (2011) 2:60. doi:10. 3389/fimmu.2011.00060
60. Lenardo $M$, Chan KM, Hornung F, McFarland H, Siegel R, Wang $\mathrm{J}$, et al. Mature $\mathrm{T}$ lymphocyte apoptosis - immune regulation in a dynamic and unpredictable antigenic environment. Annu Rev Immunol (1999) 17:221-53. doi:10. 1146/annurev.immunol.17.1.221

61. Zheng L, Trageser CL, Willerford DM, Lenardo MJ. T cell growth cytokines cause the superinduction of molecules mediating antigeninduced T lymphocyte death. J Immunol (1998) 160:763-9.

62. Green DR, Droin N, Pinkoski M. Activation-induced cell death in T cells. Immunol Rev (2003) 193:7081. doi:10.1034/j.1600-065X.2003. 00051.x

63. Zhang J, Xu X, Liu Y. Activationinduced cell death in $\mathrm{T}$ cells and autoimmunity. Cell Mol Immunol (2004) 1:186-92.

64. Ke F, Voss A, Kerr JB, O'Reilly LA, Tai L, Echeverry N, et al. BCL2 family member BOK is widely expressed but its loss has only minimal impact in mice. Cell Death Differ (2012) 19:915-25. doi:10.1038/ cdd.2011.210

65. Mason KD, Lin A, Robb L, Josefsson EC, Henley KJ, Gray DH, et al. Proapoptotic Bak and Bax guard against fatal systemic and organ-specific autoimmune disease. Proc Natl Acad Sci U S A (2013) 110:2599-604. doi:10.1073/ pnas. 1215097110

66. Willis SN, Fletcher JI, Kaufmann T, Van Delft MF, Chen L, Czabotar $\mathrm{PE}$, et al. Apoptosis initiated when $\mathrm{BH} 3$ ligands engage multiple Bcl2 homologs, not Bax or Bak. Science (2007) 315:856-9. doi:10.1126/ science. 1133289

67. Chipuk JE, Green DR. How do BCL2 proteins induce mitochondrial outer membrane permeabilization? Trends Cell Biol (2008) 18:157-64. doi:10.1016/j.tcb.2008.01.007

68. Pandiyan P, Zheng L, Ishihara S, Reed J, Lenardo MJ. CD4+CD25+Foxp3+ regulatory $\mathrm{T}$ cells induce cytokine deprivationmediated apoptosis of effector CD4+ T cells. Nat Immunol (2007) 8:1353-62. doi:10.1038/ni1536

69. Hoft DF, Farrar PL, Kratz-Owens K, Shaffer D. Gastric invasion by Trypanosoma cruzi and induction of protective mucosal immune responses. Infect Immun (1996) 64:3800-10.

70. Alberti E, Acosta A, Sarmiento ME, Hidalgo C, Vidal T, Fachado A, et al. Specific cellular and humoral immune response in Balb/c mice immunised with an expression 
genomic library of Trypanosoma cruzi. Vaccine (1998) 16:60812. doi:10.1016/S0264-410X(97) 00228-4

71. Sullivan NL, Eickhoff CS, Zhang $X$, Giddings OK, Lane TE, Hoft DF. Importance of the CCR5-CCL5 axis for mucosal Trypanosoma cruzi protection and B cell activation. J Immunol (2011) 187(3):1358-68. doi:10.4049/jimmunol.1100033

72. Hoft DF, Eickhoff CS. Type $1 \mathrm{immu-}$ nity provides optimal protection against both mucosal and systemic Trypanosoma cruzi challenges. Infect Immun (2002) 70:6715-25. doi:10. 1128/IAI.70.12.6715-6725.2002

73. Hoft DF, Eickhoff CS. Type 1 immunity provides both optimal mucosal and systemic protection against a mucosally invasive, intracellular pathogen. Infect Immun (2005) 73:4934-40. doi:10.1128/ IAI.73.8.4934-4940.2005

74. Giddings OK, Eickhoff CS, Smith TJ, Bryant LA, Hoft DF. Anatomical route of invasion and protective mucosal immunity in Trypanosoma cruzi conjunctival infection. Infect Immun (2006) 74:5549-60. doi:10. 1128/IAI.00319-06

75. Shikanai-Yasuda MA, Carvalho NB. Oral transmission of Chagas disease. Clin Infect Dis (2012) 54:84552. doi:10.1093/cid/cir956

76. Andrade ZA, and Silva HR. Parasitism of adipocytes by Trypanosoma cruzi. Mem Inst Oswaldo Cruz (1995) 90:521-2. doi:10.1590/ S0074-02761995000400018

77. Buckner FS, Wilson AJ, Van Voorhis WC. Detection of live Trypanosoma cruzi in tissues of infected mice by using histochemical stain for betagalactosidase. Infect Immun (1999) 67:403-9.

78. Guarner J, Bartlett J, Zaki SR, Colley DG, Grijalva MJ, Powell MR. Mouse model for Chagas disease: immunohistochemical distribution of different stages of Trypanosoma cruzi in tissues throughout infection. Am J Trop Med Hyg (2001) 65:152-8.

79. Correa-de-Santana E, Paez-Pereda M, Theodoropoulou M, Kenji Nihei O, Gruebler Y, Bozza M, et al. Hypothalamus-pituitaryadrenal axis during Trypanosoma cruzi acute infection in mice. $J$ Neuroimmunol (2006) 173:12-22. doi:10.1016/j.jneuroim.2005.08. 015

80. Qvarnstrom Y, Schijman AG, Veron V, Aznar C, Steurer F, Da Silva AJ. Sensitive and specific detection of Trypanosoma cruzi DNA in clinical specimens using a multi-target real-time PCR approach. PLoS Negl Trop Dis (2012) 6:e1689. doi:10. 1371/journal.pntd.0001689

81. Cortez M, Silva MR, Neira I, Ferreira D, Sasso GR, Luquetti AO, et al. (2006). Trypanosoma cruzi surface molecule gp90 downregulates invasion of gastric mucosal epithelium in orally infected mice. Microbes Infect 8:36-44. doi:10. 1016/j.micinf.2005.05.016

82. Veloso VM, Guedes PM, Andrade IM, Caldas IS, Martins HR, Carneiro $\mathrm{CM}$, et al. Trypanosoma cruzi: blood parasitism kinetics and their correlation with heart parasitism intensity during long-term infection of Beagle dogs. Mem Inst Oswaldo Cruz (2008) 103:528-34. doi:10.1590/ S0074-02762008000600003

83. Castro-Sesquen YE, Gilman RH, Yauri V, Cok J, Angulo N, Escalante $\mathrm{H}$, et al. Detection of soluble antigen and DNA of Trypanosoma cruzi in urine is independent of renal injury in the guinea pig model. PLoS ONE (2013) 8:e58480. doi:10.1371/ journal.pone.0058480

84. Morocoima A, Rodriguez $M$, Herrera L, Urdaneta-Morales S. Trypanosoma cruzi: experimental parasitism of bone and cartilage. Parasitol Res (2006) 99:663-8. doi:10.1007/s000436-006-0211-2

85. Baena Teran R, Arancibia A, Basquiera AL, De La Fuente JL, Ricchi B, De Diller AB. Trypanosoma cruzi in the bone marrow. $\mathrm{Br}$ J Haematol (2012) 157:1. doi:10. 1111/j.1365-2141.2012.09049.x

86. Da Costa SC, Calabrese KS, Bauer PG, Savino W, Lagrange PH. Studies of the thymus in Chagas' disease: III. Colonization of the thymus and other lymphoid organs of adult and newborn mice by Trypanosoma cruzi. Pathol Biol (Paris) (1991) 39:91-7.

87. Andrade LO, Machado CR, Chiari E, Pena SD, Macedo AM. Differential tissue distribution of diverse clones of Trypanosoma cruzi in infected mice. Mol Biochem Parasitol
(1999) 100:163-72. doi:10.1016/ S0166-6851(99)90035-X

88. Rachid MA, Teixeira AL, Barcelos LS, Machado CR, Chiari E, Tanowitz $\mathrm{HB}$, et al. Role of endothelin receptors in the control of central nervous system parasitism in Trypanosoma cruzi infection in rats. $J \mathrm{Neu}$ roimmunol (2010) 220:64-8. doi:10. 1016/j.jneuroim.2010.01.008

89. Vago AR, Andrade LO, Leite AA, D'avila Reis D, Macedo AM, Adad SJ, et al. Genetic characterization of Trypanosoma cruzi directly from tissues of patients with chronic Chagas disease: differential distribution of genetic types into diverse organs. Am J Pathol (2000) 156 1805-9.

90. Schijman AG, Vigliano CA, Viotti RJ, Burgos JM, Brandariz S, Lococo BE, et al. Trypanosoma cruzi DNA in cardiac lesions of Argentinean patients with end-stage chronic chagas heart disease. Am J Trop Med Hyg (2004) 70:210-20.

91. Vago AR, Silva DM, Adad SJ, Correa-Oliveira R, D'avila Reis D. Chronic Chagas disease: presence of parasite DNA in the oesophagus of patients without megaoesophagus. Trans $R$ Soc Trop Med Hyg (2003) 97:308-9. doi:10.1016/ S0035-9203(03)90155-6

92. Staquicini DI, Martins RM, Macedo S, Sasso GR, Atayde VD, Juliano MA, et al. (2010). Role of GP82 in the selective binding to gastric mucin during oral infection with Trypanosoma cruzi. PLoS Negl Trop Dis 4:e613. doi:10.1371/ journal.pntd.0000613

93. Kuhn RE, Vaughn RT, Iannuzzi NP. The in vivo distribution of $51 \mathrm{Cr}$ labeled Trypanosoma cruzi in mice. Int J Parasitol (1974) 4:585-8. doi: 10.1016/0020-7519(74)90022-8

94. Nogueira N, Gordon S, Cohn Z. Trypanosoma cruzi: modification of macrophage function during infection. J Exp Med (1977) 146:157-71. doi:10.1084/jem.146.1.157

95. Yoshida N. Trypanosoma cruzi infection by oral route: how the interplay between parasite and host components modulates infectivity. Parasitol Int (2008) 57:105-9. doi: 10.1016/j.parint.2007.12.008

96. DePaolo RW, Kamdar K, Khakpour S, Sugiura Y, Wang W, Jabri
B. A specific role for TLR1 in protective $\mathrm{T}(\mathrm{H}) 17$ immunity during mucosal infection. J Exp Med (2012) 209:1437-44. doi:10.1084/ jem.20112339

97. Pepper M, Linehan JL, Pagan AJ, Zell T, Dileepan T, Cleary PP, et al. Different routes of bacterial infection induce long-lived TH1 memory cells and short-lived TH17 cells. Nat Immunol (2010) 11:83-9. doi: 10.1038/ni.1826

98. Sallusto F, Lenig D, Forster R, Lipp M, Lanzavecchia A. Two subsets of memory $\mathrm{T}$ lymphocytes with distinct homing potentials and effector functions. Nature (1999) 401:70812. doi: $10.1038 / 44385$

99. Barbosa-Ferreira JM, Nobre AF, Maldonado JG, Borges-Pereira J, Zauza PL, Coura JR. Stroke in a chronic autochthonous Chagasic patient from the Brazilian Amazon. Rev Soc Bras Med Trop (2010) 43:751-3. doi:10.1590/ S0037-86822010000600034

Conflict of Interest Statement: The authors declare that the research was conducted in the absence of any commercial or financial relationships that could be construed as a potential conflict of interest.

Received: 15 April 2013; accepted: 13 July 2013; published online: 26 July 2013.

Citation: de Meis J, Barreto de Albuquerque J, Silva dos Santos D, Farias-de-Oliveira DA, Berbert LR, Cotta-de-Almeida $V$ and Savino $W$ (2013) Trypanosoma cruzi entrance through systemic or mucosal infection sites differentially modulates regional immune response following acute infection in mice. Front. Immunol. 4:216. doi: 10.3389/fimmu.2013.00216

This article was submitted to Frontiers in Immunological Memory, a specialty of Frontiers in Immunology.

Copyright (๑) 2013 de Meis, Barreto de Albuquerque, Silva dos Santos, Farias-deOliveira, Berbert, Cotta-de-Almeida and Savino. This is an open-access article distributed under the terms of the Creative Commons Attribution License, which permits use, distribution and reproduction in other forums, provided the original authors and source are credited and subject to any copyright notices concerning any third-party graphics etc. 